causative agents, come in for discussion. In addition to six chapters of a more or less general character, some fourteen chapters are devoted to insects in relation to disease, two chapters to arachnids in the same connexion, together with a chapter on venomous and urticarial arthropods and a final one dealing with the utilization of arthropods in medical practice.

Written in a clear, terse style, a great deal of valuable information is compressed in rather fewer than 600 pages. Prof. Herms's book can be confidently recommended as an up-to-date guide to its subject.

\section{The Genuine Works of Hippocrates}

Translated from the Greek by Dr. Francis Adams. Pp. ix $+384+8$ plates. (London: Bailliere, Tindall and $\operatorname{Cox}, 1939$.$) 13s. 6 d$.

$\mathrm{T}$ HIS volume appears to be a reproduction in book form of Francis Adams' translation for the Sydenham Society in 1849, which Dr. Emerson Crosby Kelly, the editor, had already published in Medical Classics for September, October and November, 1838. It contains the following works of Hippocrates which Adams regarded as genuine: The Oath, On Ancient Medicine, On Airs, Waters and Places, On the Prognostics, On Regimen in Acute Diseases, First and Third Books of the Epidemics, On Injuries of the Head, On the Surgery, On Fractures, On the Articulations, Mochlicus, Aphorisms, the Law, On Ulcers, On Fistulæ, On Hæmorrhoids, and On the Sacred Disease. The present edition has the advantage over the Sydenham Society's publication in consisting of only one volume instead of two, but this has been effected by the omission of (1) Adams's Preliminary Discourse, which deals with the life of Hippocrates, his disquisition on the authorship of the different treatises attributed to Hippocrates, and the physical philosophy of the ancients, (2) Adams's introductions to the various treatises contained in the volume, and (3) almost all the footnotes as well as a considerable number of the entries of the index. The present edition, therefore, will be more acceptable to the general reader than to the medical historian, who will miss the learned commentaries of one of the most famous authorities in classical Greek medicine.

\section{Miscellany}

The Official Year Book of the Scientific and Learned Societies of Great Britain and Ireland

With a Record of Publications issued during Session 1938-1939. Compiled from Official sources. Fiftysixth annual issue. Pp. vii +175 . (London: Charles Griffin and Co., Ltd., 1939.) 10s.

$\mathrm{N}$ spite of the dislocation of the work of scientific and learned societies by the War, the publishers state in their preface to this useful reference book that they hope to continue to produce it. Indeed, in view of present difficulties, it is a matter for congratulation that the book has appeared so promptly, and that no increase has been made in the price.
The volume is slightly larger than last year's issue, and contains the usual information relating to the addresses, publications and other activities of scientific and learned institutions, including such official bodies as the Department of Scientific and Industrial Research. In many cases the bodies referred to will no doubt have war-time addresses, but it may be assumed that correspondence addressed to their permanent homes will eventually reach them.

The Theory and Practice of General Science

By H. S. Shelton. Pp. 123. (London: Thomas Murby and Co., 1939.) 3s. $6 d$. net.

MR. SHELTON'S book is written chiefly in 1 support of a detailed syllabus of general science, which he has arranged in the form of topics, and it may be said at once that the syllabus is a good one. He himself seems to be in no doubt about it, for he writes: "To those who desire to found a course of general science, it can be said quite simply and clearly : Here it is for the first time in a simple, intelligible and coherent form". Mr. Shelton is severely critical of all other syllabuses of general science, especially those which have recently been compiled by the Science Masters' Association. HA seems, however, to have misunderstood their aim, which was not to mark the end of thought, but to display a content of teaching material which masters could employ in arranging their own schemes of work. For this purpose, the form in which the S.M.A. printed its material is more useful than Mr. Shelton's, since it can be adapted more easily to special circumstances.

\section{Outlines of the History of Architecture}

Part 4: Modern Architecture, with particular reference to the United States. By Prof. Rexford Newcomb. Pp. xv+318. (New York: John Wiley and Sons, Inc.; London: Chapman and Hall, Ltd., 1939.) 20s, net.

TN the history of architecture class at the University 1 of Illinois, Prof. Rexford Newcomb found it necessary to devise means whereby both lecturer and students could make fuli use of their opportunities. In these courses, which are largely presented by the illustrated lecture method, the students were compelled to write almost continuously in a darkened room, and much of the consequent distraction from the subject itself was obviated by supplying them with mimeographed sheets giving bibliographies, references, class assignments and directions-in fact, all the routine notes the writing down of which has no exercise value. From these sheets this very unusual book has been developed, and the author has done well to preserve and publish the valuable digest of the facts and examples on which his lectures were based. The fourth volume of the series is concerned with modern architecture-say from the beginning of the eighteenth century-and while American architecture is more freely referred to, historical, bibliographic and other data are collated from France, Great Britain, Germany, the Low Countries and Scandinavia. 